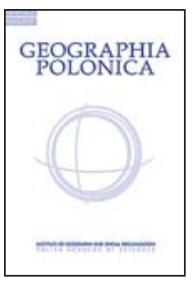

\title{
TYPOLOGY OF PHYSICAL-GEOGRAPHICAL REGIONS IN POLAND IN LINE WITH LAND-COVER STRUCTURE AND ITS CHANGES IN THE YEARS 1990-2006
}

\section{Damian Łowicki • Andrzej Mizgajski}

\author{
Adam Mickiewicz University \\ Faculty of Geographical and Geological Sciences \\ Dzięgielowa 27, 61-680 Poznań: Poland \\ e-mail addresses: damian.lowicki@amu.edu.pl; andrzej.mizgajski@amu.edu.pl
}

\begin{abstract}
The authors used a division of Poland into physical-geographical regions to present diversity in terms of land cover, and to distinguish a typology of natural units (mesoregions), in terms of both the nature of the said cover in 2006, and changes in that cover over the two time intervals 1990-2000 and 2000-2006. Individual mesoregions were assigned to the different types in regard to the two periods, this making it possible to illustrate the regional distribution of land-cover changes in Poland, with account taken of stability on the one hand, or changes as regards trends on the other. The results obtained may provide objective premises for the selection of representative spatial units in geographical, as well as landscape or ecological, research.
\end{abstract}

\section{Key words}

land-cover changes - division into physical-geographical regions - regional divisions - Corine Land Cover - Poland

\section{Introduction}

The spatial diversity of the environment - understood as the natural surroundings of human beings together with the products of material culture - represents one of the fundamental research areas for geographers. In the second half of the previous century, in Central and Eastern Europe in particular, regionalization methods were developed to select relatively uniform spatial units and to arrange them into hierarchies. Attempts at dividing the country into physical-geographical regions have also been made and are still being made in Poland - see work by Krygowski (1961), Bartkowski (1968), Żynda (1978), Czeppe and German (1980) and Niewiarowski and Kot
(2011). Among other concepts, there was general acceptance of the decimal division developed by Kondracki $(1955,1974)$, as presented in the Polish National Atlas; the last version of this appearing in the Atlas of the Republic of Poland (Kondracki \& Richling 1994). This offers a hierarchical system by which to arrange Poland's physical-geographical regional units. The procedure used in delimitation is based around differences in the origin and nature of relief and lithology (as these reflect features of stable environmental components), as well as on the more labile components and forms of use of these environments by humans that follow on from basic environmental conditioning. Units designated in this manner are characterized by specific physiognomic traits, this ensuring ease 
of use in landscape research, e.g. Bogdanowski (1973), Bielecka (2007), Kozieł (2007), Śleszyński (2007) and Dmowska (2008). The hierarchical regionalization of Poland may be used more broadly in presenting diversity and change in the spatial structure of human activity, as expressed through land use. In the methodological aspect, it opens up the area of research into the contemporary natural conditions of use of the environment and, in the practical aspect, it enhances the basis for concepts and spatial development plans on the national and regional scales to be updated.

Changes in land-use structure in Poland are used as an index of anthropogenic pressure on the natural environment and serve as a significant element to landscape development (Łowicki 2008b; Solon 2008a). The reduction of information on the landscape to that concerning the structure of land use, in lowland areas especially, is something that facilitates analysis as cartographic research methods, including quantitative analyses and visualization on maps, are made use of. This in turn allows for formalized comparison of landscape changes (Łowicki \& Mizgajski 2005), research into usefulness as regards individual functions (Wyrzykowski 1991) and classification (Solon 2008b). A special trend to contemporary research involves the recognition of changes in land use within the framework of research on the spatial development of cities and urban areas in contexts that are natural, e.g. Matuszyńska (2001), economic, e.g. Luchter (1997), Małuszyńska (2000), or architectural, e.g. Przegon (2011). As data concerning land use are collected for the entire country in line with the administrative division, the borders of each unit of local administration in Poland known as the gmina are used as the basic units in landscape-ecological research (Łowicki 2008a; Solon 2011) - this despite the obvious failure to reflect changeability of environmental conditions.

The first map of Poland's land use was entitled "Land use", and was prepared in 1916 by Eugeniusz Romer, on the scale 1:5,000,000 (after Ciołkosz \& Bielecka 2005). After the World War II, numerous attempts were made to create maps of land use on a more detailed scale. Unfortunately, the vast workload required by such detailed studies would continue to ensure failures of the project to extend across the whole area of Poland. A first map of land use within the post-War borders of Poland (at a scale of 1:1,000,000 and on the basis of topographic maps of that scale) was prepared by Uhorczak (1969). Later land-use maps were created for the whole area of Poland on the basis of satellite images rather than mapping. The first map of Poland's land cover based on images provided by the LANDSAT satellite was published in 1980, at a scale of 1:500,000 (Ciesielski \& Ciołkosz 1980). This and subsequent maps have provided the source for numerous specialised publications. The synthesizing map published in the Atlas of the Republic of Poland is particularly worth mentioning, as it offered a regional division of Poland's landscapes (Richling et al. 1995). The development of remote-sensing techniques popularized the term 'land cover', as similar to the concept of 'land use', which usually corresponds to land development. However, these two terms may not be regarded as synonymous. The term 'land cover' reflects a physiognomic aspect, while a specific type of land use reflects the form of utilization by people. The importance of land-use changes being monitored in support of regional development programs, as well as the management of water resources and quality, and the management of natural resources, has gained the recognition of both the European Commission and the European Environment Agency (EEA), these organizations being the founders of the Corine Land Cover project (CLC) of 1990, whose scope extended to the then Member States, as well as to the EU candidate countries. Updates were generated in the years 2000 and 2006, and a further one is in preparation. Common access to relatively uniform CLC databases has demonstrably increased interest in their use in spatial analyses, e.g. Wawer and Nowocień (2006), Kozieł (2008), Solon (2008b).

The start of the CLC project coincided with a key economic transition event in Poland's history. The opportunity to examine social and economic transformation arose, not only in respect of statistical indicators, but also in the spatial dimension, by reference to changes in land use. Social and economic changes associated with the transformation did indeed result in an increased volume of landscape changes, these mainly relating to the processes of suburbanisation, recreational development, the elimination of roadside trees and avenues, and the devastation of historical spatial systems (Kistowski 2006). Specifically, changes in land use associated with the transformation in Poland stem from factors of an economic, administrative, legal and social nature. The economic factors are taken to include the privatisation of state prop- 
erty and the emergence of numerous small and medium-sized enterprises, as well as decreased support for agriculture and a consequent divergence of development potentials between urban and rural areas. The effect was a rapid increase in developed areas at the expense of agricultural land. Some agricultural land was also left fallow or afforested. These are phenomena operating at the level of whole villages (Skowronek et al. 2005). In the transition period, the numbers of livestock decreased gradually, in line with a transfer of production from small farms to larger facilities reflecting the need for expensive imported feeds (Zegar 2003). There were also landscape consequences in the form of a decline in the area of pastureland (Mizgajski 2003). Among administrative and legal factors, the most important in this period was the introduction of local government in 1990. Since then, spatial planning and changes in land development have been controlled by local authorities. Control has in part been exercised by way of local spatial plans, though these are not mandatory, and so are far from universal. It is in fact more common for local authorities to issue building permits by means of individual decisions, rather than on the basis of spatial management plans. The effect of this is a dispersion of buildings and an overall extension of built-up areas. The social factor that has become fundamental to the shaping of the landscape is in turn the right to private property. Property owners want to use their land at their own discretion, notwithstanding the conflict this generates when set against common needs at local, regional or even national levels.

As GIS techniques and access to vector-based databases have developed, research on landscape typology and regionalisation has become widespread (Gulinck et al. 2001; Solon 2008b; Van Eetvelde \& Antrop 2009). These use land cover as one of the landscape features, alongside soil quality, potential vegetation, and terrain characteristics. These studies commonly also take account of rates of composition and configuration of patches of land cover. It can be concluded that the studies so far have been efficient in recognizing the structure of land cover at the landscape level.

The main aims of the work detailed in this article has been to present the regional diversity to landcover structure in Poland, as well as contemporary changes in that structure on the basis of CLC data for the years 1990-2006. Analysis was conducted for 316 mesoregions treated as the lower hierar- chical level of a division of Poland into physicalgeographical regions. The results obtained, as augmented by the available analytical database (www.geokompleks.amu.edu.pl) allow for the identification of regional units (mesoregions) characterized by different types of spatial structure and directions to changes. Objective premises are thus offered for the selection of representative spatial units for use in geographical research, as well as studies in landscape ecology. The in-depth diagnosis of changes in land cover over the period of systemic transformation can be treated as a synthetic indicator of the quality and dynamics of economic processes occurring on a regional scale, with the effect that findings should stimulate planning and legislative action alike.

\section{Materials and methods}

The Corine Land Cover (CLC) databases from the years 1990, 2000 and 2006 were used to analyze land cover in Poland. A direct comparison of data from the years 1990 and 2006 proved to be impossible, as the databases were adjusted during the programme. Thus, for the years 19902000, areas smaller than 25 ha were isolated, while for the years 2000-2006 considerations were confined to areas larger than 25 ha. This resulted in differences in the surface area balance and ensured that the databases from the years 1990 and 2000, and from the years 2000 and 2006, were compared separately from each other.

The research questions considered involved:

- the defining of characteristics of land cover for the year 2006, as well as the changes affecting selected land-cover elements in Poland's mesoregions in the 1990-2000 and 2000-2006 time intervals,

- the distinguishing of mesoregion types in Poland in line with their characteristic land cover in 2006,

- the distinguishing of mesoregions types in Poland in line with changes in the shares of developed land and forest cover in the years 1990-2000 and 2000-2006.

The research was conducted using descriptive statistics and spatial analysis of mesoregions in line with the size of changes in the surface areas of the most important land-cover types. A vector map for the division of Poland into regions was drawn up on the basis of a raster graphics image at a scale of 1:1,500,000 from the Atlas of the 
Republic of Poland (Kondracki \& Richling 1994). The land cover for the country as a whole was presented in line with the CLC database for the years 1990, 2000 and 2006, including subdivisions at the first level of detail, i.e. artificial surfaces, agricultural areas, forests and semi-natural areas and bodies of water. The names of the land-cover types were used in line with CLC nomenclature.

The typology of mesoregions on the basis of land-cover structure has been based on the proportions of three main types of cover accounting for nearly $98 \%$ of Poland's surface area, i.e. agricultural areas, forests and semi-natural areas and artificial surfaces. The adopted definitions are consistent with the CLC description, although it needs to be remembered that the vast majority of agricultural areas represent arable land, while the percentage of semi-natural areas is very low when compared with that of forests, while artificial surfaces are dominated by urban fabric.
With a view to the method of designating mesoregion types being formalized, use was made of borderline values of $+/-0.5$ standard deviation (SD) from the mean for the country as a whole. A type of cover was regarded as dominant if its share in the surface area of the mesoregion was higher than +0.5 SD; while types of cover with a share falling within the range from -0.5 to 0.5 SD were regarded as accompanying land cover. The principles underpinning the classification into mesoregions are as presented in Table 1.

The synthetic diagnosis of changes in land-cover structure in mesoregions was based on analysis of increases in the share of two land-cover types: artificial surfaces and forests. These accounted for $73 \%$ of all increases in the years $1990-2000$ and $84 \%$ of the increases in the years 2000-2006, and increase in their share usually took place at the expense of agricultural land. Mesoregion types according to land-cover changes were designated

Table 1. Methodology for the classification of Poland into mesoregions in line with characteristic land cover in 2006.

\begin{tabular}{|c|c|c|c|}
\hline \multirow{2}{*}{ Type of mesoregion } & \multicolumn{3}{|c|}{$\begin{array}{l}\text { Share of land-cover } \\
\text { types measured in SD }\end{array}$} \\
\hline & $\begin{array}{l}\text { artificial } \\
\text { surfaces }\end{array}$ & $\begin{array}{l}\text { forests and } \\
\text { semi-natural areas }\end{array}$ & $\begin{array}{l}\text { agricultural } \\
\text { areas }\end{array}$ \\
\hline 1 Distinctly artificial & $(+)$ & $(-)$ & $(-)$ \\
\hline 1.1 Distinctly artificial and averagely forested & $(+)$ & (0) & $(-)$ \\
\hline $\begin{array}{l}\text { 1.2 Distinctly artificial and averagely } \\
\text { agricultural-forested }\end{array}$ & $(+)$ & $(0)$ & $(0)$ \\
\hline $\begin{array}{l}\text { 1.3 Distinctly artificial and averagely } \\
\text { agricultural }\end{array}$ & $(+)$ & $(-)$ & (0) \\
\hline 2 Distinctly forested & $(-)$ & $(+)$ & $(-)$ \\
\hline 2.1 Distinctly forested and averagely artificial & $(0)$ & $(+)$ & $(-)$ \\
\hline $\begin{array}{l}2.2 \text { Distinctly forested and averagely } \\
\text { agricultural }\end{array}$ & $(-)$ & $(+)$ & $(0)$ \\
\hline $\begin{array}{l}\text { 2.3 Distinctly forested and averagely } \\
\text { agricultural-artificial }\end{array}$ & $(0)$ & $(+)$ & (0) \\
\hline 3 Distinctly agricultural & $(-)$ & $(-)$ & $(+)$ \\
\hline 3.1 Distinctly agricultural and averagely artificial & $(0)$ & $(-)$ & $(+)$ \\
\hline $\begin{array}{l}\text { 3.2 Distinctly agricultural and averagely } \\
\text { forested }\end{array}$ & $(-)$ & $(0)$ & $(+)$ \\
\hline $\begin{array}{l}\text { 3.3 Distinctly agricultural and averagely } \\
\text { forested-artificial }\end{array}$ & $(0)$ & $(0)$ & $(+)$ \\
\hline 4 Forested-artificial & $(+)$ & $(+)$ & $(-)$ \\
\hline 5 Agricultural-artificial & $(+)$ & $(-)$ & $(+)$ \\
\hline 6 Diversified & $(-)$ or $(0)$ & $(-)$ or $(0)$ & $(-)$ or $(0)$ \\
\hline
\end{tabular}

(+) $\mathrm{SD}>0.5 ;(0)+0.5 \geq \mathrm{SD} \geq-0.5 ;(-) \mathrm{SD}<-0.5$ 
separately for the 1990-2000 and 2000-2006 time intervals (Tab. 2).

Table 2. The methodology for mesoregion classification in Poland in connection with the character of the main land-cover changes in the years 1990-2000 and 2000-2006.

\begin{tabular}{|c|c|c|c|}
\hline \multirow{2}{*}{\multicolumn{2}{|c|}{ Types of change }} & \multicolumn{2}{|c|}{$\begin{array}{c}\text { Changes in the shares } \\
\text { of land-cover types measured } \\
\text { in SD }\end{array}$} \\
\hline & & $\begin{array}{l}\text { artificial } \\
\text { surfaces }\end{array}$ & $\begin{array}{l}\text { forests and } \\
\text { semi-natural } \\
\text { areas }\end{array}$ \\
\hline A & urbanization & $(+)$ & $(-)$ or $(0)$ \\
\hline B & afforestation & $(-)$ or $(0)$ & $(+)$ \\
\hline C & $\begin{array}{l}\text { afforestation- } \\
\text { urbanization }\end{array}$ & $(+)$ & $(+)$ \\
\hline D & stable & $(-)$ or $(0)$ & $(-)$ or $(0)$ \\
\hline
\end{tabular}

$(+) \mathrm{SD}>0.5 ;(0)+0.5 \geq \mathrm{SD} \geq-0.5 ;(-) \mathrm{SD}<-0.5$

The following types of trend for changes in land cover in mesoregions were observed:

A) Urbanisation - a significant increase in artificial surfaces with insignificant changes where the share of forest is concerned.

B) Afforestation - a significant increase in afforested areas with insignificant changes in the share of artificial surfaces.

C) Afforestation-urbanization - a parallel significant increase in the share of forests and artificial surfaces.

D) Stable - a lack of significant changes in the share of either forests or artificial surfaces.

Individual mesoregions were assigned to the different types in respect of each of the periods under analysis, this making it possible to illustrate the regional distribution of land-cover changes in Poland, with account being taken of either stability or changes in trends.

\section{Results}

\section{The land-cover structure in $\mathbf{2 0 0 6}$ and its spatial diversity}

Agricultural land occupies by far the largest area in Poland (Tab. 3). 70\% of it is arable, while the rest consists of pastures, as well as heterogeneous agricultural areas. A considerable part of the country also falls within the category of forests and semi-natural areas, the latter almost in their entirety comprising forests and types of cover connected with them (transitional woodland-scrub), while semi-natural areas occur at most marginally. $80 \%$ of artificial surfaces are occupied by urban fabric, while $8.5 \%$ are occupied by industrial and commercial units. Bodies of water constitute $70 \%$ of water areas, while over $90 \%$ of wetlands consist of inland marshes.

Table 3. Poland's land-cover structure in 2006.

\begin{tabular}{|l|c|c|}
\hline \multicolumn{1}{|c|}{ Land-cover type } & $\begin{array}{c}\text { Area } \\
\text { [thous. ha] }\end{array}$ & \multicolumn{1}{c|}{$\begin{array}{c}\text { Area } \\
{[\%]}\end{array}$} \\
\hline Artificial surfaces & 1,256 & 4.0 \\
Agricultural areas & 19,701 & 62.5 \\
Forests and semi-natural areas & 9,867 & 31.3 \\
Wetlands & 109 & 0.3 \\
Bodies of water & 591 & 1.9 \\
\hline Total & 31,524 & 100.0 \\
\hline
\end{tabular}

Source: based on CLC 2006.

Distinctly-agricultural mesoregions are the most numerous, together accounting for a $37 \%$ share of the area of Poland. There are also a large number of mesoregions - some $30 \%$ of the total, accounting for $35 \%$ of Poland overall - which lack any distinctive share of any cover type. Less than $25 \%$ of Poland's mesoregions (accounting for 20\% of Poland) are to be defined as distinctly forested, while approximately $10 \%$ (6\% of Poland) falls within the category of artificial surfaces. The rest of the mesoregions combine the agricultural and artificial or forested and artificial types (Tab. 4).

Table 4. Number and area of mesoregions in Poland in terms of characteristic land cover in 2006.

\begin{tabular}{|c|l|c|c|}
\hline Type & Name of type & $\begin{array}{c}\text { Number of } \\
\text { mesoregions }\end{array}$ & $\begin{array}{c}\text { Area of } \\
\text { mesoregions } \\
\text { [thous. ha] }\end{array}$ \\
\hline 1 & distinctly artificial & 29 & 1,838 \\
2 & distinctly forested & 73 & 6,348 \\
3 & distinctly agricultural & 100 & 11,670 \\
4 & forests-artificial & 6 & 89 \\
5 & agricultural-artificial & 12 & 650 \\
6 & diversified & 96 & 10,928 \\
\hline Total & & 316 & 31,524 \\
\hline
\end{tabular}

Source: based on CLC 2006.

The distinctly agricultural type is represented by mesoregions of Central Poland falling within 
the macroregions of the Northern Lowland and Central Masovian Lowland, the Chełmno-Dobrzyń Lakeland and the eastern part of the Wielkopolska Lakeland (Fig. 1). For example, the share of agricultural land on the Inowroctaw Plain and Kutno Plain reaches $90 \%$.

Mesoregions in which no dominance of any types of land cover is to be observed are present in large numbers all over Poland. Lowest numbers are to be found in the central part of the country: in the South Pomeranian and Wielkopolska Lakelands, as well as in the Southern Wielkopolska Lowland and the Central and North Masovian Lowland, which are distinctly dominated by agricultural areas.

Mountainous mesoregions are markedly forested areas, especially the Tatra Mountains, in which forest cover reaches $93 \%$. The distinctly forested type is also represented by mesoregions of the Southern Baltic and Eastern Baltic Lakelands, 17 in number. Their average level of forest cover is $62 \%$, while the share of artificial surfaces is just over $1 \%$.

The largest mesoregions with a considerable above-average share of artificial surfaces are associated with large agglomerations: the Tri-
City agglomeration comprising Gdańsk, Gdynia and Sopot; Warsaw and other cities in the Mid Vistula Valley; and the Upper Silesian Conurbation as well as the Łódź agglomeration. The Kashubia Coast forms the most urbanized region in Poland. The urban areas of Gdańsk, Gdynia and Sopot together with adjacent areas occupy over $31 \%$ of the mesoregion's surface area, while agricultural land accounts for just $45 \%$ and forests for $16 \%$.

\section{Changes in the land cover}

The greatest changes in land cover in the years 1990-2000 and in the years 2000-2006 affected forests and artificial surfaces. Increases in the area of forests account for $37 \%$ of all changes in land cover during the first period and for $44 \%$ of changes in the second. Over each of the time intervals, the area covered by forest increased by c. 20,000 ha. Changes of similar magnitude affected the artificial surfaces. As Table 5 shows, $80 \%$ of the forests and artificial surfaces appearing did so at the expense of agricultural areas.

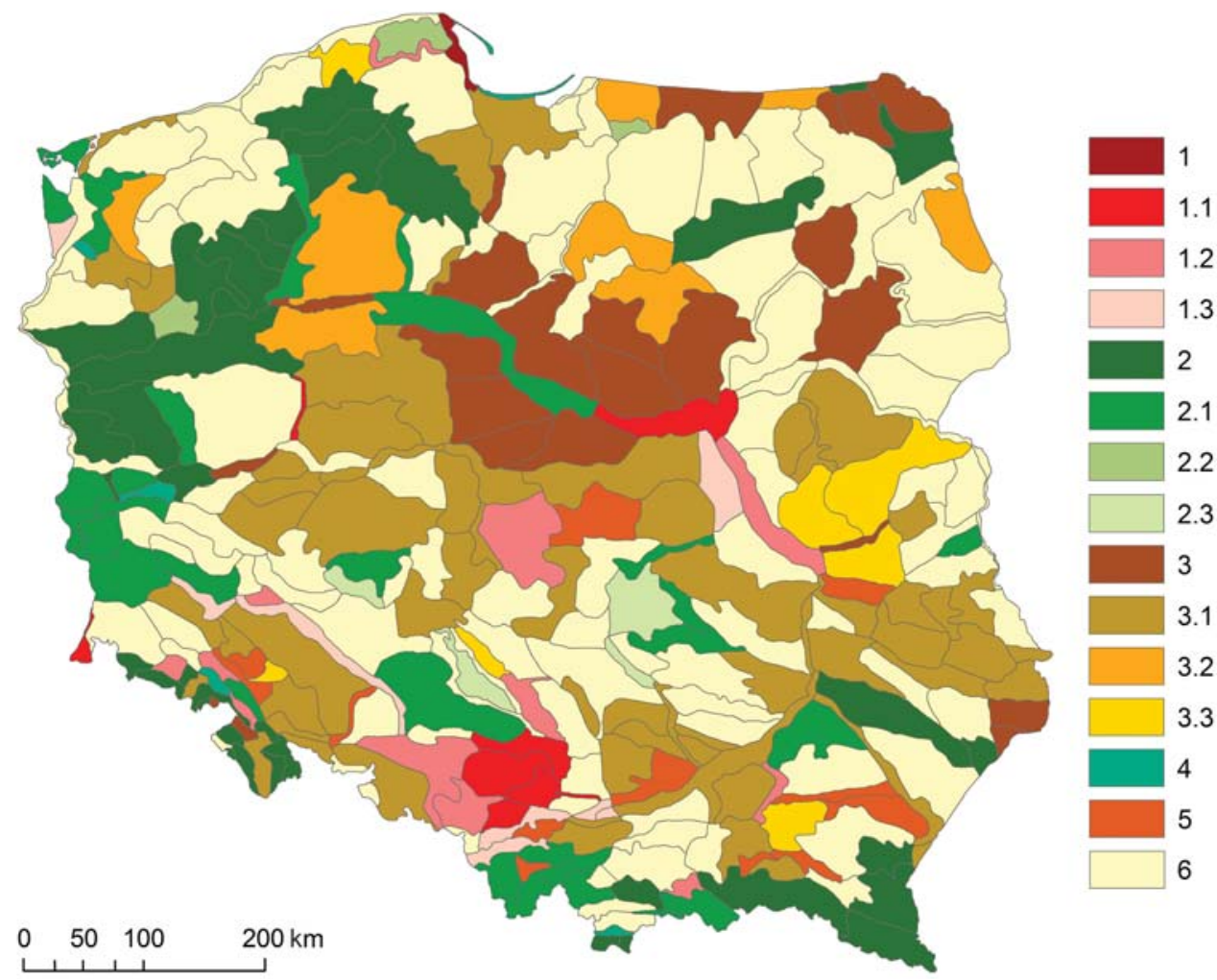

Figure 1. Classification of Poland's mesoregions by dominant forms of land cover in 2006. Markings as in Table 1. 
Forests are the second cover type which supported the increase in artificial surfaces, mostly urban fabric, industrial areas and mine sites. At the same time, the reverse process also occurred as the reclamation of post-mine sites by means of afforestation took place in the areas of Konin and Turek, Bełchatów, Sosnowiec, Tarnobrzeg and Bogatynia. Another situation characterized the Biebrza Valley and Wetlands, wherein 3,000 ha of wetlands became overgrown as a result of succession. Another type of change involved the formation of small bodies of water, created mostly at the expense of meadows (e.g. in the Middle Noteć Valley) and at former mineral extraction sites (e.g. in the vicinity of Kazimierz Biskupi and the area around Ropa in the Beskid Niski range).

A comparative analysis of trends where changes in land cover in the 1990-2000 and 2000-2006 periods are concerned allows for the distinguishing of four types of mesoregion (Tab. 6). The stable type of land cover occurs the most frequently here, no significant changes being revealed as regards land cover when set against the national average. The afforestation type offers the second most numerous characterization of type of mesoregion, and this is also true as regards total surface areas, equating to 12 and $17 \%$ of Poland (in the periods 1990-2000 and 2000-2006 respectively). Mesoregions in which the share of artificial surfaces and forest has increased markedly are the least numerous. A comparison of the number of mesoregions with specific trends for development characteristic of both time intervals makes it possible to note a significant increase in the number and surface area of mesoregions belonging to the 'urbanization' and 'afforestation-urbanization' types. In the

Table 5. Matrix of land-cover changes in hectares in the years 1999-2000 (a) and 2000-2006 (b).

\begin{tabular}{|c|c|c|c|c|c|c|c|}
\hline \multicolumn{2}{|c|}{ Changed from } & $\begin{array}{l}\text { Artificial } \\
\text { surfaces }\end{array}$ & $\begin{array}{l}\text { Agricultural } \\
\text { areas }\end{array}$ & $\begin{array}{c}\text { Forests } \\
\text { and semi-natural } \\
\text { areas }\end{array}$ & Wetlands & $\begin{array}{l}\text { Bodies } \\
\text { of water }\end{array}$ & $\begin{array}{c}\text { Area } \\
\text { decrease }\end{array}$ \\
\hline Artificial surfaces & $\begin{array}{l}a \\
b\end{array}$ & & $\begin{array}{l}2,221.1 \\
3,396.3\end{array}$ & $\begin{array}{l}2,045.6 \\
3,824.0\end{array}$ & $\begin{array}{l}0.0 \\
0.0\end{array}$ & $\begin{array}{r}797.7 \\
1,799.4\end{array}$ & $\begin{array}{l}5,064.4 \\
9,019.7\end{array}$ \\
\hline Agricultural areas & $\begin{array}{l}a \\
b\end{array}$ & $\begin{array}{l}17,146.6 \\
17,333.9\end{array}$ & & $\begin{array}{l}14,888.4 \\
18,032.7\end{array}$ & $\begin{array}{r}243.6 \\
0.0\end{array}$ & $\begin{array}{l}4,600.2 \\
2,354.3\end{array}$ & $\begin{array}{l}36,878.8 \\
37,720.9\end{array}$ \\
\hline $\begin{array}{l}\text { Forests and } \\
\text { semi-natural areas }\end{array}$ & $\begin{array}{l}a \\
b\end{array}$ & $\begin{array}{l}2,516.9 \\
2,864.0\end{array}$ & $\begin{array}{r}1,215.8 \\
118.0\end{array}$ & & $\begin{array}{r}345.1 \\
0.0\end{array}$ & $\begin{array}{l}474.4 \\
284.2\end{array}$ & $\begin{array}{l}4,552.2 \\
3,266.2\end{array}$ \\
\hline Wetlands & $\begin{array}{l}a \\
b\end{array}$ & $\begin{array}{r}181.5 \\
30.0\end{array}$ & $\begin{array}{r}2,251.1 \\
0.0\end{array}$ & $\begin{array}{r}2,999.3 \\
0.0\end{array}$ & & $\begin{array}{r}2,777.5 \\
75.2\end{array}$ & $\begin{array}{r}8,209.4 \\
105.2\end{array}$ \\
\hline Bodies of water & $\begin{array}{l}a \\
b\end{array}$ & $\begin{array}{r}120.3 \\
18.2\end{array}$ & $\begin{array}{r}101.5 \\
34.9\end{array}$ & $\begin{array}{r}186.0 \\
42.1\end{array}$ & $\begin{array}{r}44.6 \\
0.0\end{array}$ & & $\begin{array}{r}452.4 \\
95.2\end{array}$ \\
\hline Area increase & $\begin{array}{l}a \\
b\end{array}$ & $\begin{array}{l}19,965.3 \\
20,246.1\end{array}$ & $\begin{array}{l}5,789.5 \\
3,549.2\end{array}$ & $\begin{array}{r}20,119.3 \\
21,898.8\end{array}$ & $\begin{array}{r}633.3 \\
0.0\end{array}$ & $\begin{array}{l}8,649.8 \\
4,513.1\end{array}$ & $\begin{array}{r}\text { Total: } 55,157.2 \\
50,207.2\end{array}$ \\
\hline
\end{tabular}

Source: based on CLC 1990, 2000 and 2006.

Table 6. Classification of Poland's mesoregions in line with the dominant changes in land-cover in the years 1990-2000 and 2000-2006.

\begin{tabular}{|c|c|c|c|c|c|}
\hline \multirow{2}{*}{\multicolumn{2}{|c|}{ Types of change }} & \multicolumn{2}{|c|}{$1990-2000$} & \multicolumn{2}{|c|}{$2000-2006$} \\
\hline & & $\begin{array}{c}\text { number } \\
\text { of mesoregions }\end{array}$ & $\begin{array}{c}\text { area of mesoregions } \\
\text { [thous. ha] }\end{array}$ & $\begin{array}{c}\text { number } \\
\text { of mesoregions }\end{array}$ & $\begin{array}{c}\text { area of mesoregions } \\
\text { [thous. ha] }\end{array}$ \\
\hline A & urbanization & 19 & 1,544 & 39 & 4,683 \\
\hline B & afforestation & 39 & 3,782 & 39 & 5,261 \\
\hline C & afforestation-urbanization & 2 & 77 & 6 & 692 \\
\hline $\mathrm{D}$ & stable & 256 & 26,063 & 232 & 20,830 \\
\hline \multicolumn{2}{|c|}{ Total } & 316 & 31,466 & 316 & 31,466 \\
\hline
\end{tabular}

Source: based on CLC 1990, 2000 and 2006. 
first case, the number doubled and the surface area tripled, while in the second, the number doubled and the surface area increased ninefold.

An analysis of the trends to changes in the share of forest and artificial surfaces in mesoregions revealed that in $70 \%$ of spatial units, no change in the trends had occurred within the time intervals under analysis (Fig. 2). No distinct reversals of a developmental trend were to be observed in any of the mesoregions over the second time interval as compared with the first. Rather, observed changes mostly entailed reinforcement of an existing trend in the second period, while the first was characterized by stability of cover-type proportions (in 20\% of mesoregions). In $10 \%$ of the units, the trend was suppressed and land-cover proportions in the second period become stable. In three cases, changes of trend from the urbanization or forest type to the urbanization-forest type were observed.

The Gniezno Lakeland is a mesoregion displaying a consistent trend as regards an increased share of artificial surfaces (type A), especially in the Konin Industrial District and the Poznań agglomeration. A similar consistent trend is to be observed for the Szczerców Basin, in which the mineral extraction sites and power industry district of Bełchatów is situated. A considerable increase in artificial surfaces in both periods also occurred in the Warsaw Basin and the Warsaw Lowland, this reflecting the spatial development of the metropolitan area of Poland's capital. It is characteristic that a transfer from stable cover structure in the first period to an increase in the share of artificial surfaces in the second period took place in mesoregions situated near units in which the increase in artificial surfaces was ongoing. In the years 2000-2006, a significant increase in artificial surfaces occurred in 29 mesoregions, which, as compared with the national average in the years 1990-2000, did not manifest a distinct developmental trend (transfer from type $D$ to type A). These are the Łowicz-Błonie Lowland, the Mid Vistula Valley within which a part of Warsaw is located, as well as the Poznan Lakeland and the Września Lowland, where the largest part of the Poznań agglomeration is situated. It was in the

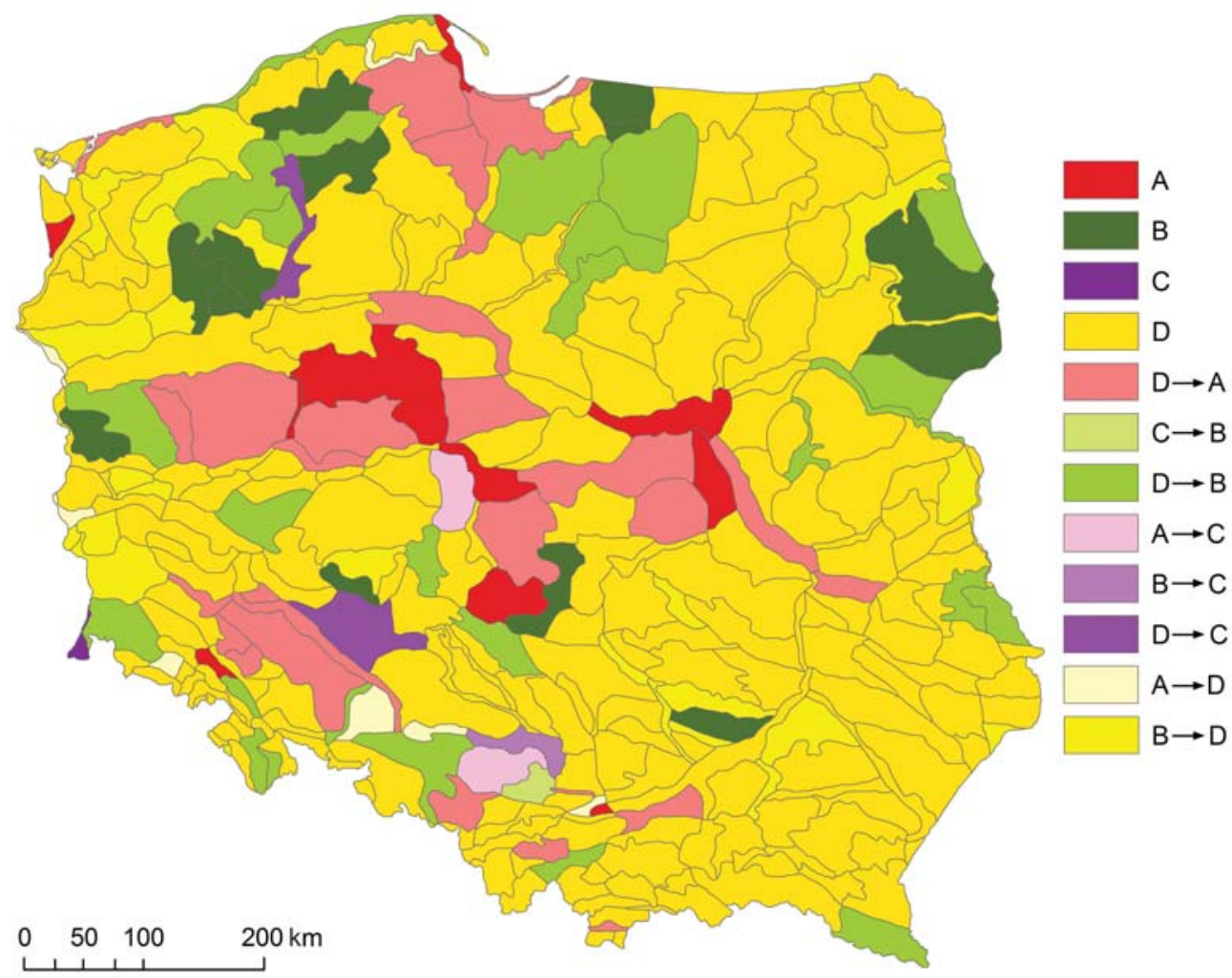

Figure 2. Trends for land-cover changes in Poland's mesoregions in the periods 1990-2000 and 2000-2006. Description as in Table 6. 
two latter units that the rate of increase in artificial surfaces was greatest, increasing more than threefold in the years 2000-2006, as compared to the years 1990-2000. The reasons for such an intensified dynamic can be seen, not only in the spatial development of the Poznań agglomeration, but also in motorway construction taking place in the Nowy Tomyśl, Środa Wielkopolska and Września districts. These are also mesoregions (7 units) within which a reverse phenomenon was observed, i.e. a slowdown in the increase in artificial surfaces as compared with the average index (transfer from type A to type D). This pertains to: The Niemodlin Lowland with Opole, the Jelenia Góra Basin, the Reda-Łeba Ice-marginal Valley with Lębork and Wejherowo, the Freienwald Basin with Kostrzyn on the Oder River, the Zasiecka Basin, Chełm and the Cholerzyn Depression.

\section{Discussion}

The issue of political changes and their impact on land use in CEE (Central \& Eastern Europe) has been well documented. Some works concern reasons for these processes and differences between countries (Jaksch et al. 1996; Strong et al. 1996; Goetz et al. 2001; Stöber 2003). Several studies also point to the nature of the various urban agglomerations (e.g. Tasan 1999; Hamilton et al. 2005; Turok \& Mykhnenko 2007) and intra-regional distinctiveness (Mizgajski 2003). The transition to the market economy, and particularly the unification of law resulting from EU membership reduced peculiarities between countries. Simultaneously a diversification of regional development in countries took place.

The study shows changes at the regional level in Poland, in which the volume of annual land-cover changes has increased. During the years 19902000, the average area affected by changes was $258.7 \mathrm{~km}^{2} /$ year, while in the period 2000-2006 it was $312 \mathrm{~km}^{2} /$ year. This means that, in the last period, about $0.1 \%$ of the country has been changing its cover each year. This result indicates that the scale of more far-reaching local changes was relatively limited. On the other hand, Ciołkosz and Poławski (2006) pointed to limitations of the CLC project resulting from the size of the smallest division (25 ha), which precludes the registration of small-area changes.

The analysis conducted allows for comparisons as regards the changes characterizing different mesoregions within Poland. After 2000, regional differences in areas of land-cover changes were less-marked, the standard deviation for all changes reducing almost threefold in the second period. This may indicate a generally diminishing role for regional factors where the differentiation of land cover is concerned.

The research exposed urbanization and afforestation as the main processes impacting upon land-cover change. There was a significant positive correlation between the portion of built-up areas or forests in mesoregions and the magnitude of changes affecting them in both the first and second periods. Mesoregions with large shares of built-up areas or forests reported above-standard growth. This means that, on a regional scale, differences in LC structure are becoming bigger, a phenomenon that has also been noted for units of territorial administration in Poland (Łowicki 2008b; Solon 2011). Those changes may be set against opinions as to the simplification of landscape structure (Lipsky 1995; Skanes \& Bunce 1997).

The most spectacular changes are associated with urbanization. In the period 1990-2006, the so-called artificial areas in Poland increased by about $261 \mathrm{~km}^{2}$. While the average for the $1990 \mathrm{~s}$ was $15 \mathrm{~km}^{2} /$ year, post-2000 the rate was yet high$\mathrm{er}$, at $19 \mathrm{~km}^{2} /$ year on average. It was the urbanized areas in the vicinity of Poznan and in the regions of the Gniezno and Poznań Lakelands that extended most, though high rates of change were also observed in the mesoregions including the agglomerations of Warsaw, Wrocław and Gdańsk. It is widely known that forest cover in Poland has been on the increase in the entire period since World War II, in this way passing the 30\% mark in 2010. However, this remains a share below the European average, and one that is lower than in any of Poland's neighbor countries except Ukraine (CSO 2012). Furthermore, there are many mesoregions, in the central part of Poland in particular, in which the share accounted for by forests does not exceed $10 \%$. Equally, the trend towards an increase in the area of forest is becoming more marked, rather than less, and the role of driving areas is hear played by mesoregions in the northern and eastern parts of the country.

Both urbanization and afforestation takes place at the expense of agricultural land area. While more than half of Polish territory continues to be occupied by arable land, the transformation did activate a steady and widespread reduction in 
areas accounted for by this form of use. In urban regions, agricultural areas are increasingly seen as potential areas for development, rather than as sites for agricultural production. A reduction in areas of arable land over the last two decades has also been typical for other CEECs and northern European countries in which an agricultural landscape dominates (Mander \& Jongman 1998; Peterson \& Aunap 1998).

In the case of afforestation, we are dealing with a decrease in the area of poor soils being used agriculturally, these being released from agricultural production specifically with tree planting in mine. In contrast, the urbanization process is tending to eliminate cultivated soils irrespective of quality, it being far from unusual for areas of the best soils to be lost. This decrease in the area of potentially the most productive soils is a consequence of Poland's inefficient spatial planning system. As of 2009, only $25 \%$ of the country was covered by local spatial management plans (GUS 2013). In remaining areas, changes in land use have been of a rather ad hoc and spontaneous nature.

Where land-cover changes in the observed periods are concerned, it is urbanization that emerges as the most significant process differentiating the mesoregions. There is a need for continued observation of this process, since multifunctional urbanized landscapes are changing very fast (Antrop 2004). Despite the decline in the diversity of changes affecting the mesoregions after 2000, the percentage of mesoregions with a clear trend towards urbanization has doubled. These results indicate that the urbanization processes ongoing in major metropolitan areas are reflected at regional level. The opposite trend for a reduction in the urbanized area is to be observed in just a few cases. There is a different status in the case

\section{References}

Antrop M., 2004. Landscape change and the urbanization process in Europe. Landscape and Urban Planning, vol. 67, issues 1-4, pp. 9-26.

BARTKOWSKI T. (ed.), 1968. Podział Polski północno-zachodniej na regiony fizyczno-geograficzne. Prace Wydziału Biologii i Nauk o Ziemi. Seria Geografia, no. 4. Poznań: Uniwersytet Adama Mickiewicza, 204 pp. of forests, with the number of mesoregions manifesting progressing afforestation being similar to the number showing the opposite trend.

\section{Conclusions}

The study examined the share of the main types of land cover, e.g. agricultural, forest or artificial areas in natural units in Poland, as these relate to the national average. The differences between mesoregions observed in this regard offer only an incomplete reflection of the general structure to land cover in Poland, because the mesoregions have been created on the basis of morphogenetic criteria only to some degree coinciding with the land-cover pattern.

In most regional units the proportions of the basic land-cover types are close to average. Such 'normal' regions are spread throughout Poland.

The vast majority of regions had a stable spatial structure over both of the time intervals considered, while just around $30 \%$ of units display clear changes for any of the land-cover types.

The research findings presented here may be of use as geographical and landscape/ecological regional studies are assessed for their representativeness. They may also serve the purposes of comparative research relevant to land use and landscape structure. Analysis of the type employed here could gain further use in spatial policy seeking to assess, and as necessary control, the directions development processes are taking, as well as the efficiency of instruments being applied.

Editors' note:

Unless otherwise stated, the sources of tables and figures are the author(s), on the basis of their own research.

BieleCKA E., 2007. Możliwości wykorzystania bazy danych o pokryciu terenu Corine Land Cover do kartowania i analizowania krajobrazu. [in:] K. Ostaszewska (ed.), Znaczenie badań krajobrazowych dla zrównoważonego rozwoju, Warszawa: Uniwersytet Warszawski. Wydział Geografii i Studiów Regionalnych, pp. 505-518.

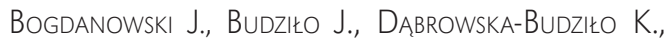
Flagorowska L., Genga W., Łuczyńska-Bruzda M., PAWŁowsKa K., 1973. Krajobraz Polski. Ochrona 
i kształtowanie dla rekreacji. Teka Komisji Urbanistyki i Architektury, vol. 7, pp. 21-34.

Ciesielski J., CloŁkosz A. (eds.), 1980. Polska. Mapa użytkowania ziemi. 1:500,000, Warszawa: Instytut Geodezji i Kartografii, Polskie Przedsiębiorstwo Wydawnictw Kartograficznych.

Ciotkosz A., BieleckA E., 2005. Pokrycie terenu w Polsce. Bazy danych Corine Land Cover. Biblioteka Monitoringu Środowiska, Warszawa: Państwowa Inspekcja Ochrony Środowiska, 76 pp.

CloŁkosz A., PoŁAwskı Z.F., 2006. Zmiany użytkowania ziemi w Polsce w drugiej połowie XX wieku. Przeglad Geograficzny, vol. 78, no. 2, pp. 173-190.

CSO, 2012. Ochrona Środowiska. Environment 2012. Central Statistical Office. Regional and Environmental Surveys Department, Warszawa: Zakład Wydawnictw Statystycznych, 599 pp. http://www.stat.gov. $\mathrm{pl} / \mathrm{cps} / \mathrm{rde} / \mathrm{xbcr} / \mathrm{gus} / \mathrm{se}$ _ochrona_srodowiska_2012. pdf [10 September 2013].

Czeppe Z., German K., 1980. Regiony fizyczno-geograficzne miejskiego województwa krakowskiego. Komisja Nauk Geograficznych PAN. Oddział w Krakowie, Folia Geographica. Series Geographica-Physica, vol. 13, Kraków: Zakład Narodowy im. Ossolińskich, pp. 117-143.

DMowska A., 2008. Klasyfikacja Pojezierzy Południowobałtyckich i Pojezierzy Wschodniobałtyckich w oparciu o kryterium morfometryczne. Landform Analysis, vol. 9, pp. 345-347.

Goetz S.J., Jaksch T., Siebert R. (eds.), 2001. Agricultural transformation and land use in Central and Eastern Europe. Aldershot: Ashgate, 340 pp.

Gulinck H., Mugica M., de LuCiO J.V., Atauri J.A., 2001. A framework for comparative landscape analysis and evaluation based on land cover data, with an application in the Madrid region (Spain). Landscape and Urban Planning, vol. 55, no. 4, pp. 257-270.

GUS, 2013. Bank Danych Lokalnych. Główny Urząd Statystyczny, http://www.stat.gov.pl/bdl/app/strona. html?p_name=indeks [8 August 2013].

Hamilton F.E.l., Dimitrovska Andrews K., PichlerMilanovic N., 2005. Transformation of cities in Central and Eastern Europe: Towards globalization. TokyoNew York: United Nations University Press, 536 pp.

JAKSCH T., BORK H.-R., DalChOW C. (eds.), 1996. Landnutzung in Mittel- und Osteuropa: natürliche Bedingungen, land- und forstwirtschaftliche Nutzungspotentiale, Transformationsprozeß und ländlicher Raum. Budapest: Mezögazda Kiadó, 271 pp.

KIstowski M., 2006. Propozycja metody identyfikacji, waloryzacji i formułowania zaleceń ochronnych zasobów krajobrazu przyrodniczego i kulturowego. Problemy Ekologii Krajobrazu, vol. 18, pp. 75-85.
KondRACKI J., 1955. Problematyka fizyczno-geograficznej regionalizacji Polski. Przegląd Geograficzny, vol. 27, no. 2, pp. 298-309.

KONDRACKI J., 1974. Regiony fizycznogeograficzne. [in:] Narodowy Atlas Polski, Warszawa: Instytut Geografii i Przestrzennego Zagospodarowania PAN, Zakład Narodowy im. Ossolińskich, pl. 41.

Kondracki J., Richling A., 1994. Regiony fizycznogeograficzne. 1:1,500,000. [in:] M. Najgrakowski (ed.), Atlas Rzeczypospolitej Polskiej, Warszawa: Instytut Geografii i Przestrzennego Zagospodarowania PAN, Główny Geodeta Kraju.

KozIEt M., 2007. Zróżnicowanie pokrycia terenu mezoregionów województwa lubelskiego wg podziału Kondrackiego. [in:] M. Strzyż, A. Świercz (eds.), Badania regionalne - wybrane problemy, Nauki Geograficzne w badaniach regionalnych, vol. 3, Kielce: Instytut Geografii Akademii Świętokrzyskiej, pp. 203-209.

KozIEt M., 2008. Application of the Corine Land Cover 2000 database to landscape structure analysis of selected protected areas in Poland. Problemy Ekologii Krajobrazu, vol. 20, pp. 279-285.

KRYGOWSKI B., 1961. Geografia fizyczna Niziny Wielkopolskiej. Geomorfologia. Część 1. Poznań: Poznańskie Towarzystwo Przyjaciół Nauk, Wydawnictwo Naukowe PWN, 203 pp.

LIPSKYZ., 1995. The changing face of Czech rural landscape. Landscape and Urban Planning, vol. 31, no. 1, pp. 39-45.

LUCHTER B., 1997. Zmiany w zagospodarowaniu centralnej części Krakowa w okresie transformacji (ze szczególnym uwzględnieniem lat 1992-1995). Zeszyty Naukowe. Akademia Ekonomiczna w Krakowie, no. 483, pp. 121-134.

ŁowICKI D., 2008a. Zmiany krajobrazu województwa wielkopolskiego od poczatku transformacji ustrojowej. Poznań: Wydawnictwo Naukowe UAM, 121 pp.

ŁowICKI D., 2008b. Land use changes in Poland during transformation. Landscape Urban Planning, vol. 87, no. 4, pp. 279-288.

ŁowICKI D., Mizgasski A., 2005. Zmiany krajobrazu kulturowego Wielkopolski w okresie transformacji i opisujace je kategorie użytkowania terenu. Przegląd Geograficzny, vol. 77, no. 4, pp. 551-568.

MatuszYŃSKa E., 2000. Przemiany strefy podmiejskiej aglomeracji poznańskiej. [in:] R. Domański (ed.), Nowe problemy rozwoju wielkich miast i regionów, Biuletyn KPZK PAN, vol. 192, pp. 265-289.

Mander Ü., Jongman R.H.G., 1998. Human impact on rural landscapes in central and northern Europe. Landscape and Urban Planning, vol. 41, no. 3, pp. 149-153.

MATUSZYŃSKA I., 2001. Zmiany użytkowania terenu jako element transformacji środowiska przyrodniczego na obszarze wybranych zlewni Poznania i jego strefy 
podmiejskiej. Poznań: Wydawnictwo Poznańskiego Towarzystwa Przyjaciół Nauk, 160 pp.

Mizgajski A., 2003. Grundzüge und Triebkräfte der Kulturlandschafsentwicklung In der WielkopolskaWojewodschaft im Zuge des postsozialistischen Transformationsprozesses. Hallesches Jahrbuch für Geowissenschaften, Reihe A: Geographie und Geooekologie, Band 25, Halle (Saale), pp. 79-86.

Niewiarowski W., Kot R., 2011. Delimitation and characteristics of natural landscapes of the ChełmnoDobrzyń Lakeland, Urszulewo Plain and the neighbouring Vistula and Drwęca valley. Geographia Polonica, vol. 84, no. 1, pp. 33-59.

Peterson U., Aunap R., 1998. Changes in agricultural land use in Estonia in the 1990s detected with multitemporal Landsat MSS imagery. Landscape and Urban Planning, vol. 41, no. 3, pp. 193-201.

Przegon W., 2011. Zmiany użytkowania ziemi na przykładzie miasta Podgórza i Zamościa w świetle materiałów kartograficznych. Kraków: Wydawnictwo Naukowe "Akapit", 216 pp.

Richling A., LeWandowski W., Dąrowski A., 1995. Wykorzystanie krajobrazu. [in:] M. Najgrakowski (ed.), Atlas Rzeczypospolitej Polskiej, Warszawa: Instytut Geografii i Przestrzennego Zagospodarowania PAN, Główny Geodeta Kraju.

SkAnes H.M., Bunce R.G.H., 1997. Direction of landscape change (1741-1993) in Virestad, Sweden - characterized by multivariate analysis. Landscape and Urban Planning, vol. 38, no. 1, pp. 61-75.

Skowronek E., Krukowska R., ŚwieCa A., Tucki A., 2005. The evolution of rural landscapes in mid-eastern Poland as exemplified by selected villages. Landscape and Urban Planning, vol. 70, no. 1, pp. 45-56.

Solon J., 2008a. The review of chosen approaches to landscape typology. Problemy Ekologii Krajobrazu, vol. 20, pp. 25-33.

SOLON J., 2008b. Types of cultural landscape of Poland. Problemy Ekologii Krajobrazu, vol. 20, pp. 109-115.

Solon J., 2011. Main directions of landscape changes in Poland in years 1995-2009. Problemy Ekologii Krajobrazu, vol. 30, pp. 95-104.

StöBER G. (ed.), 2003. Der Transformationsprozess in (Ost-)Deutschland und in Polen. Hannover: Verlag Hahnsche Buchhandlung, 192 pp.
Strong A.L., Reiner T.A., Szyrmer J.M., 1996. Transitions in land and housing: Bulgaria, the Czech Republic, and Poland. New York: St. Martin's Press, 298 pp.

ŚLESZYŃSKI P., 2007. Ocena atrakcyjności wizualnej mezoregionów Polski. [in:] K. Ostaszewska (ed.), Znaczenie badań krajobrazowych dla zrównoważonego rozwoju: profesorowi Andrzejowi Richlingowi w 70. rocznice urodzin i 45-lecie pracy naukowej, Warszawa: Uniwersytet Warszawski. Wydział Geografii i Studiów Regionalnych, pp. 697-714.

TASAN T., 1999. Warsaw under transformation: New tendencies in the housing market. GeoJournal, vol. 49, no. 1, pp. 91-103.

Turok I., Mykhnenko V., 2007. The trajectories of European cities, 1960-2005. Cities, vol. 24, no. 3, pp. 165-182.

UHORCZAK F., 1969. Polska przegladowa mapa użytkowania ziemi 1:1,000,000. Prace Geograficzne, no. 17, A. Część tekstowa + B. Część kartograficzna, Warszawa: Instytut Geografii PAN, Wydawnictwo Naukowe PWN, 35 pp. +9 maps.

van Eetvelde V., Antrop M., 2009. A stepwise multiscaled landscape typology and characterisation for trans-regional integration, applied on the federal state of Belgium. Landscape and Urban Planning, vol. 91, no. 3, pp. 160-170.

Wawer R., Nowocień E., 2006. Cyfrowa mapa występowania erozji wodnej powierzchniowej obszaru Polski z wykorzystaniem Corine Land Cover 2000. Rozdzielczość przestrzenna 500 m. Roczniki Akademii Rolniczej w Poznaniu. Rolnictwo, vol. 65, pp. 207-213.

WYRZYKOWSKI J. (ed.), 1991. Ocena krajobrazu Polski $w$ aspekcie fizjonomicznym na potrzeby turystyki. Wrocław: Uniwersytet Wrocławski, 132 pp.

ZegAR J.S. (ed.), 2003. Zróżnicowania regionalne rolnictwa. Warszawa: GUS, 263 pp.

ŻYNDA S., 1978. Podział środkowego Nadodrza na fizycznogeograficzne jednostki przestrzenne i ich ocena dla niektórych potrzeb planowania przestrzennego. Poznań: Wydawnictwo Naukowe UAM, 87 pp. 